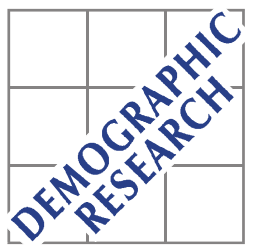

Demographic Research a free, expedited, online journal of peer-reviewed research and commentary in the population sciences published by the Max Planck Institute for Demographic Research Konrad-Zuse Str. 1, D-18057 Rostock · GERMANY www.demographic-research.org

DEMOGRAPHIC RESEARCH

VOLUME 24, ARTICLE 13, PAGES 293-312

PUBLISHED 15 FEBRUARY 2011

http://www.demographic-research.org/Volumes/Vol24/13/

DOI: 10.4054/DemRes.2011.24.13

Descriptive Findings

\title{
A note on race, ethnicity and nativity differentials in remarriage in the United States
}

\section{Catherine B. McNamee}

R. Kelly Raley

(C) 2011 Catherine B. McNamee \& R. Kelly Raley.

This open-access work is published under the terms of the Creative Commons Attribution NonCommercial License 2.0 Germany, which permits use, reproduction \& distribution in any medium for non-commercial purposes, provided the original author(s) and source are given credit.

See http:// creativecommons.org/licenses/by-nc/2.0/de/ 


\section{Table of Contents}

1 Introduction $\quad 294$

$2 \quad$ Background 295

$2.1 \quad$ R-E-N differentials in marriage and divorce 295

2.2 What do we know about remarriage patterns? 296

2.3 Did cohabitation render remarriage irrelevant? 297

3 Data and methods $\quad 298$

$4 \quad$ Results $\quad 300$

$\begin{array}{lll}5 & \text { Discussion and conclusion } & 307\end{array}$

6 Acknowledgement 308

$\begin{array}{ll}\text { References } & 309\end{array}$ 


\title{
A note on race, ethnicity and nativity differentials in remarriage in the United States
}

\author{
Catherine B. McNamee ${ }^{1}$ \\ R. Kelly Raley ${ }^{2}$
}

\begin{abstract}
The objectives of this study are to produce up-to-date estimates of race/ethnic/nativity differentials for remarriage and repartnership among women in the United States and to see if these differences are due to across-group differences in demographic characteristics. First, we produce lifetable estimates of remarriage and repartnering for white, black, U.S. born Latina and foreign born Latina women. Next, we estimate race/ethnic/nativity differentials for remarriage and repartnership using event-history analysis with and without controls for demographic characteristics. The results suggest a continued overall decline in remarriage rates, while many women repartner by cohabitating. Whites are more likely than blacks or Latinas to remarry and they are also more likely to repartner. Race/ethnic/nativity differentials remain even after accounting for variations in demographic characteristics. This suggests that race/ethnic/nativity differentials in remarriage and repartnering rates, rather than ameliorating disadvantages associated with divorce, reinforce these differentials.
\end{abstract}

\footnotetext{
${ }^{1}$ University of Texas at Austin. E-mail: catem@prc.utexas.edu.

${ }^{2}$ University of Texas at Austin. E-mail: kelly.raley@austin.utexas.edu.
} 


\section{Introduction}

Remarriage is important for evaluating theories of social change in the family and it also has practical importance for the lives of parents and children. Ongoing research has documented the continued retreat from marriage in the United States as well as in much of Europe and Asia. Most of this research has focused on the timing of first marriage; however, research on remarriage has also provided some insights, especially in the United States where rates of divorce remain high. For example, when high rates of divorce are accompanied by high rates of remarriage, it suggests that people are not rejecting marriage as an institution, but are simply dissatisfied with their particular marriage (Spanier and Glick 1980; Thornton 1977).

Additionally, remarriage can be an important life event for adults and their children. Divorce is associated with substantial declines in economic well being, especially for women and their children (Holden and Smock 1991; Smock, Manning, and Gupta 1999). Remarriage, however, can provide an additional income earner in the household and is the "surest path to economic recovery" after a divorce (Smock, Manning, and Gupta 1999: 807). Remarriage is associated with increases in income-toneeds ratios and household income, as well as decreases in poverty and welfare use (Smock, Manning, and Gupta 1999; Morrison and Ritualo 2000). Although remarriage can increase economic well-being especially if the marriage lasts, it can also contribute to family instability, which is associated with poorer child outcomes.

Many women repartner through cohabitation and this might also have implications for their well-being as well as their children's. For example, previous research has found that, unlike remarriage, repartnering through cohabitation does not bring substantial economic benefits (Morrison and Ritualo 2000). Furthermore, given the instability of nonmarital unions, cohabitation may contribute even more to family instability than remarriage (Raley and Wildsmith 2004). Families still are the primary location for childrearing and as such the core location for social investments in children (e.g., managing children's educational experiences, providing access to health care). Consequently differentials in family experiences can ameliorate or reinforce the intergenerational transmission of inopportunity.

Despite the potential relevance of remarriage for theories of social change or for studies of child well being, we know very little about recent trends and differentials in this family event (see Sweeney 2010). We know even less about differences among Latinos by nativity despite the importance of immigration for recent trends in population composition and the fact that nativity is an important source of variation in family patterns among Latinos (Oropesa and Landale 2004). The goals of this study are twofold: 1) to produce up-to-date estimates of remarriage and repartnering by race, ethnicity, and nativity (R-E-N) and 2) to explore various demographic factors that may 
account for variability in the pace of remarriage. To achieve this, we combine data from the 2006-2008 National Study of Family Growth (NSFG) and the 2004 Survey of Income Program Participation (SIPP) to produce lifetable estimates of remarriage and repartnering for U.S. born non Hispanic white, U.S. born non Hispanic black, U.S. born Latina and foreign born Latina women. We use event-history analysis to explore the extent to which R-E-N differentials in remarriage and repartnering arise from differences in other demographic characteristics such as age and the presence of children.

\section{Background}

\subsection{R-E-N differentials in marriage and divorce}

Compared to whites, blacks experience a later age at a first marriage as well as higher rates of divorce (Udry 1966; South and Spitze 1986; Ruggles 1997; Raley and Bumpass 2003; Goldstein and Kenney 2001). Moreover, the black-white differential in divorce may have been increasing over time (Sweeney and Phillips 2004, although see Teachman 2002 for contrary evidence). Generally, the family patterns of Latinos fall somewhere between those of whites and blacks, but whether they more closely resemble those of blacks or whites depends on immigrant generation and whether one focuses on marriage or divorce. Latino marriage patterns more closely resemble those of whites whereas patterns of divorce fall closer to the experience of blacks. Moreover, Latinos born in the United States are more similar in marriage and divorce patterns to blacks than are foreign born Latinos. Specifically foreign born Mexican Americans marry younger than whites, but U.S. born Mexicans marry later than whites once one accounts for Mexicans' early age at school leaving (Raley, Durden, and Wildsmith 2004). Likewise the foreign born Latino population has lower rates of divorce than whites, but U.S. born Latinos have higher rates of divorce. In fact among third and later generation Latinos, rate of divorce are similar to rates for African Americans (Bean, Berg, and Van Hook 1996).

A portion of the differences in marriage and divorce across racial, ethnic, and nativity groups can be explained by demographic factors such as age at marriage, level of education and region of residence. For instance, minorities have lower levels of education than whites, and this partially explains the higher risk of divorce among blacks and U.S. born Latinos (Sweeney and Phillips 2004; Phillips and Sweeney 2006). Yet significant differences remain net of these controls, partly because other compositional effects offset their influence. Blacks marry later than whites and age at marriage is negatively associated with the risk of divorce (eg.. Teachman 1986; Cherlin 
1992; Raley and Bumpass 2003). Thus controlling for this factor actually widens the black-white gap in the risk of marital disruption.

\subsection{What we know about remarriage patterns?}

Considering the group variations in the patterns of marriage and divorce, it is surprising that few studies have investigated the association between race/ethnicity (as well as other sociodemographic factors) and remarriage. Notable exceptions are Bumpass, Sweet and Castro Martin (1990), and Smock (1990). These studies indicate that in the 1980s, non Hispanic whites had the highest remarriage probabilities, followed by Latinos. Non Hispanic blacks have lower remarriage rates than both non Hispanic whites and Latinos (Bumpass, Sweet, and Castro Martin 1990). However patterns of variation in remarriage have not been re-examined in recent years despite the fact that trends and differentials in marriage and divorce have likely altered the sociodemographic characteristics of women "at risk" of remarriage. Further, we do not know how remarriage rates differ among U.S. born and foreign born Latina women. As mentioned above, previous research indicates that patterns of marriage and divorce among Latinas differ substantially by nativity, with the foreign born having an earlier age at first marriage and lower rates of divorce, partly because of the selective nature of the migration process and perhaps also partly because of cultural differences between those born in Mexico and those who grew up in the United States (Raley, Durden, and Wildsmith 2004; Phillips and Sweeney 2005). Research on remarriage has been scarce in recent decades, which parallels the time period when nativity differences for Latinos started appearing in demographic research. As a result, our study adds a unique piece to the remarriage literature by providing information on remarriage probabilities for Latinas by nativity.

In addition to documenting R-E-N differentials in the pace of remarriage, we wish to investigate whether these arise because of differences in the sociodemographic characteristics of divorced women. Previous research documents that age at separation, age at first marriage, the presence of children, and education are associated with remarriage probabilities. Age at separation is also negatively associated with the pace of remarriage, possibly because the pool of potential mates declines as women age or possibly because older women prefer to cohabit or to live apart together (Bumpass, Sweet, and Castro Martin 1990; Gierveld 2004). A younger age at first marriage is associated with a higher probability of remarriage, possibly because early marriage might signify an attachment to marriage or limited alternative opportunities (Bumpass, Sweet, and Castro Martin 1990; Smock 1990). 
Presence of children is also associated with a lower rate of remarriage (Koo, Suchindran, and Griffith 1984; Teachman and Heckert 1985; Bumpass, Sweet, and Castro Martin 1990; Smock 1990). The negative association between number of children and remarriage has been found to be greater for black women than white women, especially at higher parities (Koo, Suchindran, and Griffith 1984; Smock 1990).

Early research on remarriage indicated that education was negatively associated with the chance of remarriage, at least among whites. At that time researchers hypothesized that this might arise because more highly educated women had more resources to support themselves (Koo, Suchindran, and Griffith 1984; Thornton 1977). Yet, an analysis of remarriage using data from the 1987-88 NSFG indicated that education was not (any longer) associated with remarriage for white women and was positively associated with remarriage for black women (Smock 1990). Sweeney's (2002) analysis of an even more recent period shows a positive association between women's education and the pace of remarriage, but no association between educational attainment and the timing of repartnering. Altogether these results suggest that the association between educational attainment and remarriage has become more positive over time.

\subsection{Did cohabitation render remarriage irrelevant?}

Previous research shows that non marital cohabitation following divorce is common (Bumpass and Sweet 1989; Bumpass, Raley, and Sweet 1995). Thus remarriage does not adequately describe the repartnering process following divorce. Although there is no literature on racial or ethnic variation in patterns of repartnering after divorce, we have substantial reason to believe that blacks and Latinos are more likely than whites to repartner through cohabitation rather than marriage. First black-white differentials in the timing of first union are smaller than differences in marriage (Raley 1996). This is likely at least partly because the economic instability is less of an impediment for cohabitation than for marriage (Oppenheimer 2003). Additionally some have hypothesized that cohabitation is more marriage-like among Latinos than among whites (e.g., Smock 2000; Philips and Sweeney 2005; Wildsmith and Raley 2006; Manning and Landale 1996). Estimates on marriage and cohabitation prevalence reveal smaller race-ethnic differences in cohabitation than in marriage. For instance, in 2002 among women aged $15-44,63 \%$ of non Hispanic white women, $39 \%$ of non Hispanic black women, and $58 \%$ of Latinas have ever married. In comparison, $51 \%$ of both non Hispanic white women and non Hispanic black women, and 49\% of Latinas have evercohabitated. The barriers to marriage may be higher for non whites, particularly for 
blacks, whereas cohabitation occurs frequently across all race-ethnicities. Yet importantly these estimates largely reflect experiences prior to first marriage and we know very little about variation in cohabitation following the dissolution of first marriage. Consequently, a study of R-E-N differentials in remarriage would not be complete without a companion analysis of repartnering. Unfortunately, the SIPP does not include information on the timing of transitions into cohabiting unions. Consequently our analysis of repartnering uses only the recently released 2006-2008 NSFG, which does have information on the formation of cohabiting unions following separation or divorce.

\section{Data and methods}

In this study, we combine data from the 2006-2008 National Survey of Family Growth (NSFG) and the 2004 Survey of Income and Program Participation (SIPP). The SIPP is a nationally representative continuing panel survey conducted by U.S. Census Bureau. The sample consists of 62,000 households in the U.S. interviewed every four months in eight waves starting in February 2004. Our analysis employs data from topical modules on marital and fertility histories conducted during wave two of the 2004 SIPP. The Cycle 7 NSFG is a nationally representative continuous cross-sectional survey conducted by the National Center for Health Statistics for the U.S. Department of Health and Human Services. The sample design included men and women in the U.S. between the ages of 15 to 44 . We are using data collected from women in 2006-2008, totaling 7,356 female respondents.

Our analysis focuses on women, because we found in preliminary analysis that, because the NSFG sample of men is smaller than that of women, there were not enough men to produce lifetable estimates of remarriage by R-E-N even with the NSFG and SIPP combined. Moreover, the cohabitation histories were collected differently for men than for women, with interviews of men focusing only on previous spouses and the three most recent sexual partners. Prior research also suggests women tend to more accurately report dates of separation and remarriage than men (Martin 2006). Furthermore focusing on women better enables us to compare our findings to past research, which also typically describes patterns of remarriage using samples of women.

We combine the SIPP and NSFG datasets for the remarriage analyses to increase the sample size. This is particularly important when analyzing a relatively infrequent event, such as remarriage where small cell sizes can become an issue. The repartnering analysis comes solely from the NSFG as the SIPP does not provide cohabitation histories; fortunately, including both cohabitation and remarriage events for 
repartnership avoids some of the sample size concerns associated with the remarriage analysis. Additionally, because the NSFG sample is restricted to women less than age 45 in 2006-2008, we limit both NSFG and SIPP to women who separated before age 36 since 1996. (Women age 44 at the start of the NSFG interview period were up to age 35 in 1996. Consequently we can not use these data to describe remarriage patterns of women who separate after age 35). We exclude first separations prior to 1996 to provide a recent account of demographic patterns and to prevent having to make a more severe age restriction. In total, our analyses employ data on 1,599 women who separated from or divorced their first husband (600 from NSFG and 999 from SIPP.) We censor marital events post 2002 in the SIPP and twelve months prior to the interview date in the NSFG data, because we want to exclude women with separations that occur less than one year prior to the survey as they may reconcile with their partners (Binstock and Thornton 2003). Lengths of separations can vary with some couples never formally divorcing; for example, prior research suggests long-term separations are more common among black couples (McCarthy 1978; Morgan 1988). Thus we define the dissolution of marriage at the separation date, rather than the date of formal divorce. We focus our analysis on marriages and cohabitations that occur after the separation from the first marriage.

We construct a variable indicating race-ethnicity-nativity (R-E-N) by combining information from separate questions on race, Hispanic/Latino origin, and place of birth. Respondents are coded as black and white if they were coded as such on the recoded race variable and not coded Hispanic on a separate ethnicity variable. Anyone identified as Hispanic is coded either as U.S. born Latino or foreign born Latino, depending on their response to a question about whether they were born in the United States. This constructed variable has four categories, non Hispanic white (white), non Hispanic black (black), U.S. born Latino, and foreign born Latino. We exclude foreign born white women, foreign born black women, Asian non Hispanic women and other race non Hispanic women because of small sample sizes. In the combined SIPP and NSFG remarriage analysis there are 1,095 white women, 209 black women, 163 U.S. born Latina women, and 132 foreign born Latina women. For the NSFG repartnering analysis there are 352 white women, 94 black women, 78 U.S. born Latina women, and 76 foreign born Latina women. For brevity, we switch to using "white women" and "black women" to refer to U.S. born non Hispanic white women and U.S. born non Hispanic black women for the remainder of this paper.

We also include five demographic variables in the analysis: age at separation, age at first marriage, any child, premarital birth, and education. Age at separation and marriage are recoded from birth dates and dates of first separation and first marriage. Any child is a time-varying variable that identifies the women's motherhood status starting from the year of separation to year of remarriage, repartnering, or interview, 
depending on the analysis. The construction of the premarital birth variable differs by dataset. The SIPP has women identify births as premarital, while the NSFG constructs a recoded variable based on a child's date of birth and the mother's marriage dates. Education refers to level at time of interview due to substantial missing data on degree dates in the NSFG. Preliminary analysis showed little change in educational attainment after first marriage; therefore we do not believe using current education over education at first marriage affects our findings.

To estimate discrete-time hazard models of remarriage and repartnership we reconstruct the data into person-years starting from year at separation to year of remarriage or interview and year at separation to year of repartnership or interview. Our analysis begins by providing lifetable estimates of the duration until 25 percent of women have remarried or repartnered by R-E-N, age at separation, and education. To get a sense of trends in remarriage, we compare our estimates to Bumpass, Sweet, and Castro Martin (1990).

Next we describe the sociodemographic characteristics of divorced women in the SIPP and NSFG as they vary by R-E-N, including age at separation, age at first marriage, education, whether the woman had a premarital birth, and whether she has had a child. Lastly, we estimate discrete-time hazard models to examine R-E-N differentials in remarriage and repartnering, as well as the potential influence of compositional factors on R-E-N differentials in remarriage and repartnering. These models are estimated using logistic regression and we present exponentiated coefficients, representing the relative risk of remarriage (or repartnering.) To identify which compositional factors are most strongly associated with R-E-N differences in remarriage and repartnering, we estimate six models. The first model includes only RE-N, data source (in the remarriage analysis) and duration of separation as the predictors (Model 1). Models $2-5$ add each demographic composition factor separately. The final model (Model 6) includes all variables. All models are weighted to adjust for the non proportional sampling designs.

\section{Results}

Table 1 shows lifetable estimates of the number of years until $25 \%$ remarried or repartnered by R-E-N, and age at separation. By 3.8 years after separation, $25 \%$ of white women have remarried. U.S. born and foreign born Latina women have slower entry into remarriage, taking 5.1 and 5.2 years until $25 \%$ have remarried respectively. Black women had the slowest pace of remarriage and never reach $25 \%$, as only $19 \%$ had remarried after 6 years of separation (not shown). Consistent with other previous studies, the pace of remarriage steadily slows with older ages at separation. Yet, 
different from the research on remarriage in the 1970s and 1980s, we find women with less than a high school degree have the slowest pace of remarriage, taking 5.4 years until 25\% remarried. Women with high school degrees and those with advanced degrees have a similar pace of remarriage, taking 3.7 and 3.6 years respectively. Women with some college fall in between with 4.3 years.

Table 1: Number of years until $25 \%$ remarried or repartnered by sex, age at separation, and education by R-E-N, women

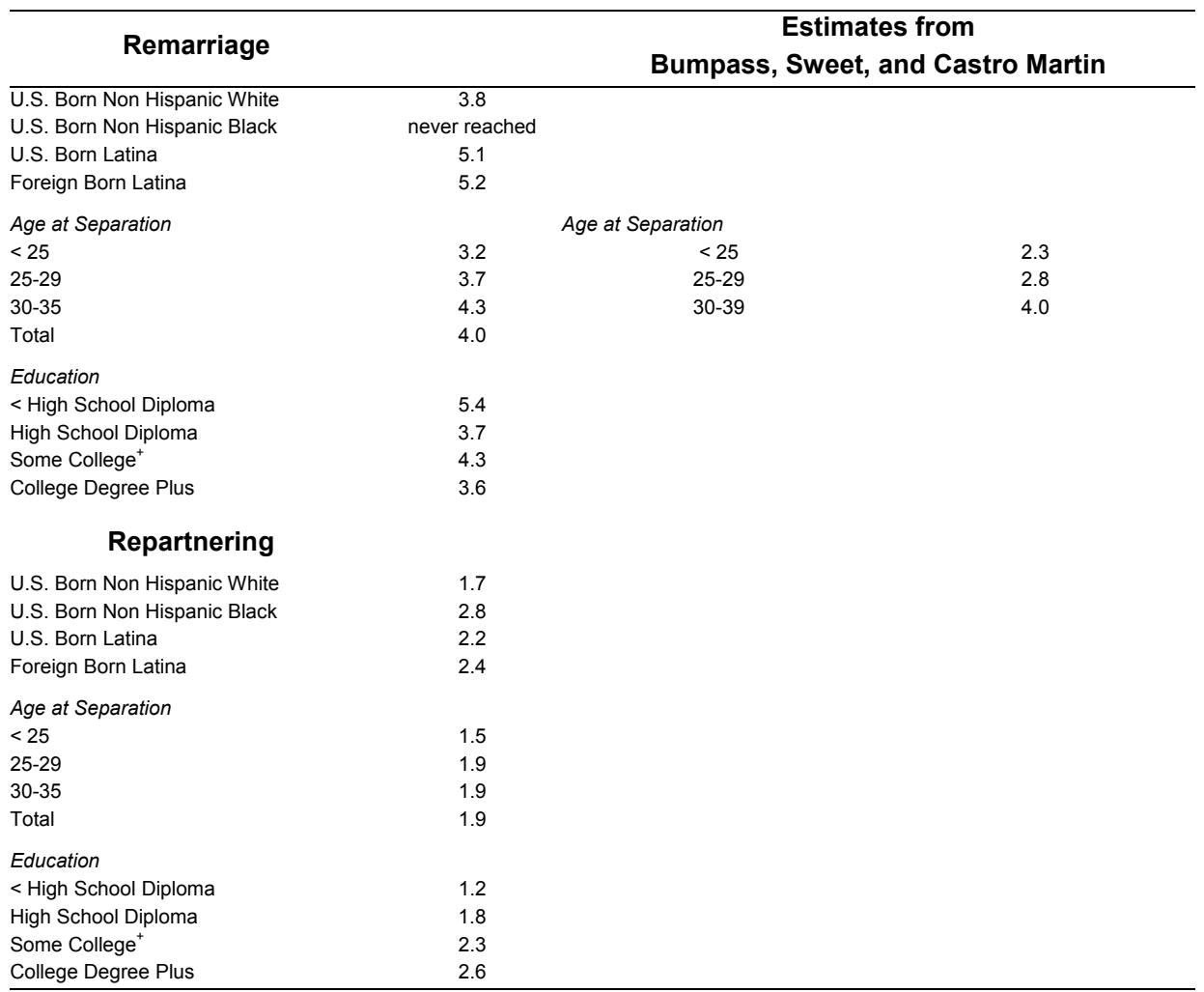

Note: Remarriage uses NSFG \& SIPP. Repartnering uses NSFG. All data is weighted. + Some college includes those who earned an Associates degree.

For comparison, Table 1 also presents estimates from Bumpass and colleagues (1990) of the pace of remarriage in 1982. Clearly remarriage rates are declining. 
Whereas in 1982 it took 2.3 years for a woman separated before age 25 to remarry, our estimate for the late 1990s and early 2000s is 3.2 years, and our estimates are longer for the other groups as well.

The bottom of Table 1 presents estimates of the pace of repartnering. The results indicate that the pace of repartnering is substantially quicker than is the case for remarriage, yet the general pattern of R-E-N differentials for repartnering mirrors that for remarriage. White women repartner more quickly than black women or Latinas. Additionally the differences in marriage or repartnering by nativity among Latinas are small.

The bottom of Table 1 also indicates that women who separate at early ages have the quickest reentry into a coresidential union with $25 \%$ repartnered in a year and a half; however, women separated between 25-29 have the same pace into repartnership as women separated between $30-35$ with $25 \%$ repartnered at about 2 years. Finally, in contrast to the patterns for remarriage, education is negatively associated with the pace of repartnering. The difference is most dramatic for women with less than a high school education. For women with less than a high school education, 25\% enter a repartnership in a little over a year, over 4 years faster than it takes to reach $25 \%$ remarried. In comparison, $25 \%$ of women with a Bachelor's degree or more have repartnered after 2 and half years, only one year faster than remarriage. The results suggest that in the United States, women with lower education levels are turning to repartnership in place of remarriage far more than women with higher levels of education.

Table 2 presents R-E-N differences in the sociodemographic characteristics of women separated before age 36 since 1996 for the remarriage analysis. Age at separation and age at first marriage varies across R-E-N, with black women disproportionately represented in the older age groups compared to white women and Latinas. The majority of black women have had a premarital birth. U.S. born Latina women are similar to blacks with $38 \%$ having had a premarital birth. Foreign born Latina and white women have similar percentages with $30 \%$ and $27 \%$ having had a premarital birth respectively. The vast majority of women have at least one child, ranging from $81 \%$ of white women to $93 \%$ of black women. White and black women have roughly similar educational distributions with over $40 \%$ obtaining some college and about $16 \%$ with a college degree or more. U.S. born Latina women have somewhat lower levels of education, with only $8 \%$ having earned a college degree. Foreign born Latina women, have the lowest levels of education, with over $40 \%$ lacking a high school diploma. Because education is positively associated with marriage, part of the lower remarriage rates among foreign born Latinas may be accounted for by their lower educational attainment. 
Table 2: $\quad$ Percent distribution of selected demographic characteristics by R-E-N: remarriage, NSFG and SIPP

\begin{tabular}{lcccc}
\hline & $\begin{array}{c}\text { U.S. Born Non } \\
\text { Hispanic White } \\
\text { 1,095 }\end{array}$ & $\begin{array}{c}\text { U.S. Born Non } \\
\text { Hispanic Black } \\
\mathbf{n = 2 0 9}\end{array}$ & $\begin{array}{c}\text { U.S. Born } \\
\text { Latina } \\
\mathbf{n = 1 6 3}\end{array}$ & $\begin{array}{c}\text { Foreign Born } \\
\text { Latina } \\
\mathbf{n = 1 3 2}\end{array}$ \\
\hline Age at Separation & 33.4 & 19.9 & 30.9 & 41.3 \\
$<25$ & 32.1 & 33.5 & 26.9 & 27.1 \\
$25-29$ & 34.5 & 46.6 & 42.2 & 31.6 \\
$30-35$ & & & & \\
Age at First Marriage & 30.6 & 14.8 & 36.5 & 46.8 \\
$<20$ & 32.2 & 27.0 & 35.1 & 22.3 \\
$20-22$ & 27.1 & 58.2 & 28.4 & 30.9 \\
$>23$ & 27.0 & 52.8 & 37.5 & 29.7 \\
Premarital Birth & 81.1 & 92.6 & 89.4 & 88.6 \\
Any Child & & & & \\
Education & 10.0 & 14.9 & 14.4 & 43.6 \\
$<$ High School Diploma & 33.9 & 23.3 & 35.0 & 26.8 \\
High School Diploma & 40.1 & 45.6 & 42.9 & 22.0 \\
Some College & 16.1 & 16.3 & 7.7 & 7.6 \\
College Degree & & & & \\
\hline
\end{tabular}

Table 3 shows odds ratios from a discrete-time event history model predicting remarriage. Model 1 replicates the findings in Table 1. Black, U.S. born Latina and foreign born Latina women all have substantially (and significantly) lower odds of remarriage compared to the odds for white women. Black women have the largest differential with $59 \%$ lower odds of remarriage compared to white women. U.S. born Latina women have the smallest differential with $34 \%$ lower odds of remarriage. Foreign born Latina women fall closer to U.S. born Latina women than to white women with $38 \%$ lower odds of remarriage. 
Table 3: Odds ratios from discrete-time event history model predicting remarriage, NSFG and SIPP

\begin{tabular}{|c|c|c|c|c|c|c|c|c|c|c|c|c|}
\hline \multirow[b]{2}{*}{ Race, Ethnicity, Nativity } & \multicolumn{2}{|c|}{ Model 1} & \multicolumn{2}{|c|}{ Model 2} & \multicolumn{2}{|c|}{ Model 3} & \multicolumn{2}{|c|}{ Model 4} & \multicolumn{2}{|c|}{ Model 5} & \multicolumn{2}{|c|}{ Model 6} \\
\hline & $\begin{array}{l}\text { Odds } \\
\text { Ratio }\end{array}$ & $\begin{array}{l}\text { Coeff. } \\
\text { I SE }\end{array}$ & $\begin{array}{l}\text { Odds } \\
\text { Ratio }\end{array}$ & $\begin{array}{l}\text { Coeff. } \\
\text { ISE }\end{array}$ & $\begin{array}{l}\text { Odds } \\
\text { Ratio }\end{array}$ & $\begin{array}{l}\text { Coeff. } \\
\text { I SE }\end{array}$ & $\begin{array}{l}\text { Odds } \\
\text { Ratio }\end{array}$ & $\begin{array}{l}\text { Coeff. } \\
\text { I SE }\end{array}$ & $\begin{array}{l}\text { Odds } \\
\text { Ratio }\end{array}$ & $\begin{array}{l}\text { Coeff. } \\
\text { I SE }\end{array}$ & $\begin{array}{l}\text { Odds } \\
\text { Ratio }\end{array}$ & $\begin{array}{l}\text { Coeff. } \\
\text { I SE }\end{array}$ \\
\hline $\begin{array}{l}\text { U.S. Born Non Hispanic } \\
\text { White }\end{array}$ & ref & & ref & & ref & & ref & & ref & & ref & \\
\hline $\begin{array}{l}\text { U.S.Born Non Hispanic } \\
\text { Black }\end{array}$ & $0.41^{* \star *}$ & -4.09 & $0.41^{* * *}$ & -4.06 & $0.41^{* \star *}$ & -3.89 & $0.43^{* * *}$ & -3.86 & $0.41^{\star \star *}$ & -4.06 & $0.42^{\star * *}$ & -1.54 \\
\hline U.S. Born Hispanic & $0.66^{*}$ & -2.18 & $0.66^{*}$ & -2.16 & $0.67^{*}$ & -2.21 & $0.67^{*}$ & -2.09 & $0.68^{*}$ & -2.00 & 0.70 & -1.54 \\
\hline Foreign Born Hispanic & $0.62^{*}$ & -2.16 & $0.62^{*}$ & -2.11 & $0.62^{*}$ & -2.28 & $0.62^{*}$ & -2.15 & 0.71 & -1.48 & 0.71 & -1.14 \\
\hline Duration since Separation & & & & & & & & & & & & \\
\hline $0-1$ & ref & & ref & & ref & & ref & & ref & & ref & \\
\hline $2-5$ & $3.46^{* * *}$ & 9.96 & $3.45^{* \star *}$ & 9.97 & $3.45^{\star \star \star}$ & 9.95 & $3.43^{\star * *}$ & 9.92 & $3.44^{\star \star \star}$ & 9.95 & $3.43^{\star \star *}$ & 7.75 \\
\hline$>6$ & 1.53 & 1.80 & 1.54 & 1.80 & 1.54 & 1.79 & 1.52 & 1.76 & 1.55 & 1.83 & 1.53 & 1.42 \\
\hline Age at Separation & & & & & & & & & & & & \\
\hline$<25$ & & & ref & & & & & & & & ref & \\
\hline $25-29$ & & & 1.15 & 1.10 & & & & & & & 1.07 & 0.34 \\
\hline $30-35$ & & & 0.90 & -0.81 & & & & & & & 0.80 & -1.07 \\
\hline Age at First Marriage & & & & & & & & & & & & \\
\hline$<20$ & & & & & ref & & & & & & ref & \\
\hline $20-22$ & & & & & 0.96 & -0.94 & & & & & 0.94 & -3.21 \\
\hline$>23$ & & & & & 1.04 & -1.52 & & & & & 1.11 & 0.49 \\
\hline Any Child & & & & & & & & & & & & \\
\hline None & & & & & & & ref & & & & ref & \\
\hline Yes & & & & & & & 1.08 & 0.55 & & & 1.20 & -1.37 \\
\hline Premarital Birth & & & & & & & & & & & & \\
\hline None & & & & & & & ref & & & & ref & \\
\hline Yes & & & & & & & $0.77^{*}$ & -2.11 & & & 0.77 & -0.74 \\
\hline Education & & & & & & & & & & & & \\
\hline$<$ High School Diploma & & & & & & & & & ref & & ref & \\
\hline High School Diploma & & & & & & & & & 1.44 & 1.88 & 1.43 & 1.18 \\
\hline Some College* & & & & & & & & & 1.43 & 1.82 & 1.44 & 1.27 \\
\hline College Degree & & & & & & & & & $1.79^{\star \star}$ & 2.71 & $1.79^{*}$ & 1.84 \\
\hline NSFG & 0.84 & -1.66 & 0.84 & -0.17 & 0.84 & -1.87 & 0.83 & -1.70 & 0.88 & -1.12 & 0.88 & -9.78 \\
\hline $\begin{array}{l}\text { Wald Model Fit Test } \\
\text { Number of Person-Years }\end{array}$ & $\begin{array}{r}\text { ref } \\
6707\end{array}$ & & $1.75(\mathrm{~ns})$ & & $.25(\mathrm{~ns})$ & & 1.90 (ns) & & 4.02(ns) & & $8.45(\mathrm{~ns})$ & \\
\hline
\end{tabular}

Notes: +some college includes those who earned an associates degree.

(ns) Not Significant at the $p<.05 ;{ }^{*}$ Significant at the $p<.05$; ${ }^{*}$ Significant at the $p<.01$; ${ }^{* \star}$ Significant at the $p<.001$.

In Models 2-5, we added each of the sociodemographic characteristics to the model separately. Adding age at separation does little to change the R-E-N differences in the odds of remarriage and likewise for models adding age at first marriage and measures of fertility. In Model 5, after educational attainment is added to the model, foreign born Latina women no longer have a significantly lower remarriage rate. Thus 
at least some of the reason why foreign born Latina women have lower remarriage rates is because they have lower levels of education and education is positively associated with the chance of remarriage. In Model 6, after adding all of the sociodemographic characteristics the black-white difference remains significant but neither Latina group is significantly different from whites. Importantly from Model 1 to Model 6, only the relative odds for foreign born Latina women changes substantially, from .62 to .71. As we just discussed, this change in the relative odds was due to controlling for educational differences, but the decline in statistical significance for Latina women, particularly U.S. born Latina women, is due to increasing standard errors. This is not surprising given our fairly small sample size, only 34 remarriages for foreign born Latina women and 24 for U.S. born Latinas. Given that the odds ratios continue to be substantially different from one, we are reluctant to conclude that controlling for sociodemographic characteristics explains U.S. born Latina women's lower remarriage rates. As an aside, in all models, we included a variable to identify data origin as NSFG or SIPP. At no point does NSFG have significantly different odds of remarriage compared to SIPP, which validates combining the datasets.

Table 4 presents the odds ratios for repartnership. Model 1 shows that repartnership differentials resemble remarriage differentials; black, U.S. born Latina and foreign born Latina women all have significantly lower odds of repartnership compared to the odds for white women. Black women again have the largest differential with $66 \%$ lower odds of repartnership. U.S. born Latina women have the second largest differential with $47 \%$ lower odds of repartnership. Resembling the patterns in remarriage, Foreign born Latina women have odds similar to U.S. born Latinas, with $42 \%$ lower odds of repartnership compared to white women. Models $2-6$ add the demographic characteristics seen in the previous remarriage analysis. The results in Model 6 reveal continued significant lower odds of repartnership for black and Latina women compared to white women. The differentials, however, become slightly smaller for black women (62\% lower odds) and for U.S. born Latina women (45\% lower odds) but larger for foreign born Latina women (65\% lower odds).

We also explored analyses that tested whether the associations between sociodemographic characteristics and the pace of remarriage or repartnering varied by R-E-N. We found no significant interactions in models predicting remarriage, but there were substantial differences in the predictors of the pace of repartnering by R-E-N. The clearest pattern we found was that the association between education and the pace of repartnering was negative for whites, blacks, and U.S. born Latinas, but positive for foreign born Latinas. That is, the association between educational attainment and repartnering is much more similar for foreign born Latinas than for any of the other RE-N groups. This might indicate that cohabitation is more marriage-like for this group. We are reluctant, however, to make any strong conclusions based on these significant 
McNamee \& Raley: A note on race, ethnicity, and nativity differentials in remarriage in the United States

interaction terms because they are based on a small sample and can sometimes change direction when other covariates are included in the models.

Table 4: Odds ratios from discrete-time event history model predicting repartnership, NSFG

\begin{tabular}{|c|c|c|c|c|c|c|c|c|c|c|c|c|}
\hline \multirow[b]{2}{*}{ Race, Ethnicity, Nativity } & \multicolumn{2}{|c|}{ Model 1} & \multicolumn{2}{|c|}{ Model 2} & \multicolumn{2}{|c|}{ Model 3} & \multicolumn{2}{|c|}{ Model 4} & \multicolumn{2}{|c|}{ Model 5} & \multicolumn{2}{|c|}{ Model 6} \\
\hline & $\begin{array}{l}\text { Odds } \\
\text { Ratio }\end{array}$ & $\begin{array}{c}\text { Coeff. } \\
\text { I SE }\end{array}$ & $\begin{array}{l}\text { Odds } \\
\text { Ratio }\end{array}$ & $\begin{array}{c}\text { Coeff. } \\
\text { I SE }\end{array}$ & $\begin{array}{l}\text { Odds } \\
\text { Ratio }\end{array}$ & $\begin{array}{c}\text { Coeff. } \\
\text { I SE }\end{array}$ & $\begin{array}{l}\text { Odds } \\
\text { Ratio }\end{array}$ & $\begin{array}{c}\text { Coeff. } \\
\text { I SE }\end{array}$ & $\begin{array}{l}\text { Odds } \\
\text { Ratio }\end{array}$ & $\begin{array}{c}\text { Coeff. } \\
\text { / SE }\end{array}$ & $\begin{array}{l}\text { Odds } \\
\text { Ratio }\end{array}$ & $\begin{array}{c}\text { Coeff. } \\
\text { I SE }\end{array}$ \\
\hline \multicolumn{13}{|l|}{ U.S. Born Non Hispanic } \\
\hline White & ref & & ref & & ref & & ref & & ref & & ref & \\
\hline \multicolumn{13}{|l|}{ U.S. Born Non Hispanic } \\
\hline Black & $0.34^{* \star \star}$ & -4.68 & $0.38^{* \star \star}$ & -4.17 & $0.38^{* * *}$ & -3.66 & $0.32^{* * *}$ & -4.88 & $0.36^{* * *}$ & -4.43 & $0.38^{* * *}$ & -3.78 \\
\hline U.S. Born Hispanic & $0.53^{* *}$ & -3.01 & $0.56^{* *}$ & -2.76 & $0.52^{\star *}$ & -3.07 & $0.51^{\star *}$ & -3.19 & $0.53^{\star \star}$ & -3.07 & $0.55^{\star *}$ & -2.28 \\
\hline Foreign Born Hispanic & $0.58^{*}$ & -2.46 & $0.50^{* *}$ & -3.06 & 0.50 ** & -3.06 & 0.56 ** & -2.60 & $0.41^{\star \star \star}$ & -3.75 & $0.35^{\star \star *}$ & -3.11 \\
\hline \multicolumn{13}{|l|}{ Duration since Separation } \\
\hline $0-1$ & ref & & ref & & ref & & ref & & ref & & ref & \\
\hline $2-5$ & $1.67^{\star \star \star}$ & 4.34 & $1.77^{\star \star \star}$ & 4.76 & $1.70^{* \star *}$ & 4.51 & $1.67^{\star \star \star}$ & 4.36 & $1.77^{\star \star \star}$ & 4.78 & $1.88^{* * *}$ & 3.21 \\
\hline$>6$ & $0.55^{*}$ & -2.10 & 0.61 & -1.71 & $0.56^{*}$ & -1.82 & $0.56^{*}$ & -2.05 & 0.63 & -1.61 & 0.69 & -1.14 \\
\hline \multicolumn{13}{|l|}{ Age at Separation } \\
\hline$<25$ & & & ref & & & & & & & & ref & \\
\hline $25-29$ & & & 0.74 * & -2.10 & & & & & & & 0.79 & -0.77 \\
\hline $30-35$ & & & $0.47^{* \star *}$ & -5.35 & & & & & & & $0.48^{* * *}$ & -2.76 \\
\hline \multicolumn{13}{|l|}{ Age at First Marriage } \\
\hline$<20$ & & & & & ref & & & & & & ref & \\
\hline $20-22$ & & & & & $0.73^{*}$ & -3.31 & & & & & 0.93 & -0.29 \\
\hline$>23$ & & & & & $0.58^{\star \star *}$ & -3.66 & & & & & 0.97 & -0.12 \\
\hline \multicolumn{13}{|l|}{ Any Child } \\
\hline None & & & & & & & ref & & & & ref & \\
\hline Yes & & & & & & & 1.19 & 1.10 & & & 1.11 & 0.43 \\
\hline \multicolumn{13}{|l|}{ Premarital Birth } \\
\hline None & & & & & & & ref & & & & ref & \\
\hline Yes & & & & & & & 1.15 & 1.09 & & & 1.13 & 0.55 \\
\hline \multicolumn{13}{|l|}{ Education } \\
\hline$<$ High School Diploma & & & & & & & & & ref & & ref & \\
\hline High School Diploma & & & & & & & & & 0.71 * & -2.06 & 0.75 & -0.91 \\
\hline Some College ${ }^{*}$ & & & & & & & & & $0.49^{* * *}$ & -4.05 & 0.51 *** & -2.42 \\
\hline College Degree & & & & & & & & & $0.37^{* \star *}$ & -4.44 & $0.46^{* *}$ & -2.23 \\
\hline Wald Model Fit Test & ref & & $10.22^{* *}$ & & $4.88(n s)$ & & $1.50(\mathrm{~ns})$ & & $11.56^{\star *}$ & & $24.65^{\star *}$ & \\
\hline Number of Person-Years & 2290 & & & & & & & & & & & \\
\hline
\end{tabular}

Notes: some college includes those who earned an associates degree+.

(ns) Not Significant at the $p<.05$; ${ }^{\star}$ Significant at the $p<.05 ;{ }^{* \star}$ Significant at the $p<.01$; ${ }^{\star \star \star}$ Significant at the $p<.001$. 


\section{Discussion and conclusion}

The main objective of this study is to describe differences in the pace of remarriage and repartnering by race, ethnic, and nativity groups, while considering the group variations in demographic characteristics. Our results point to a continued decline in remarriage rates. Repartnering makes up for some of the slower pace in remarriage, particularly for women with less than a high school degree. Our analysis also demonstrates that the black and Latina women have lower rates of remarriage than whites. Black women have the largest differentials compared to white women even controlling for compositional differences in other demographic factors. But Latina women, both U.S. born and foreign born, also have lower remarriage rates. Our analyses also suggest that R-E-N differentials in repartnering (marriage and cohabitation) echo patterns of remarriage. Whites are more likely than blacks or Latinas to remarry and they are also more likely to repartner. Moreover we find that while for most groups education is negatively associated with the pace of repartnering, it is positively associated with remarriage. The finding that education is positively associated with remarriage echoes research of remarriage in the early 1990s (Sweeney 2002). The positive association between education and remarriage may indicate that women's resources are important in facilitating remarriage, yet is it less clear why women with less education would form cohabiting unions at a relatively quick pace. This may reflect the difficulty less educated women have maintaining a household by themselves. Future research should explore this pattern more deeply.

Despite the contributions of this research towards understanding trends and differentials in family formation patterns, this research has a number of important limitations. Our research uses SIPP and NSFG data because they provide the most current representative data on marital events; however, both datasets have some weaknesses. In the SIPP, one limitation was the inability to determine the number of children respondents had ever had, because the SIPP only gathers the birth date of the first and last child. The SIPP also does not provide the month of marital events, which means that our duration measures for the SIPP are crude relative to what we can create with the NSFG. Fortunately differences in estimates of the pace of remarriage between the two data sets were not significant. Furthermore the SIPP does not collect a cohabitation history and therefore could not be used in the repartnering analysis. The primary limitation to the NSFG is the age restriction to respondents 18-44 years old. We focus our analysis therefore on younger women who separated at younger ages, but this means that this analysis does not describe remarriage among women who separate after age 35 and remarriage frequently occurs in older ages. Additionally while the SIPP provides information that allows us to distinguish first generation Latinas from Latinas born in the U.S., we can not distinguish second, third, or higher order generations 
among the U.S. born. SIPP also does not provide information on country of origin; therefore we can not specify the country of origin for Latina respondents. Grouping Latinas into one panethnic category underplays possible variations within this group. A potentially fruitful line of future research would be to investigate remarriage variations across generational status and country of origin.

Despite these weaknesses, this research fills an important gap in knowledge by updating estimates of remarriage and describing differences in remarriage and repartnering by race, ethnicity, and nativity. Interestingly remarriage rates continue to decline. Once we could point to the high rates of remarriage as an indicator that people were not disillusioned with the institution of marriage, just unhappy with their particular marriage. Does the decline in remarriage suggest a shift in the status of marriage? We do not think so. Most youth today still want to marry and most will marry, suggesting that we are still strongly attached to marriage (see also for example Cherlin 2009). It is notable that women with the most resources, as measured by educational attainment, are the most likely to remarry quickly after a separation. This suggests that declines in remarriage may have more to do with constraints than preferences.

Additionally our results describing patterns in remarriage mirror recent patterns in divorce. Blacks and U.S. born Latinas as well as women with lower levels of education have higher rates of divorce and lower rates of remarriage compared to white women and those with a college degree. This suggests that differentials in remarriage rates, rather than ameliorating disadvantages associated with divorce, reinforce these differentials. Importantly, we have not shown that divorce causes economic hardship or that this effect is similar across race-ethnic differentials. So, we can not say for certain that divorce and remarriage patterns contribute to race-ethnic (or nativity) differentials in economic well being. Yet prior research strongly suggests that divorce actually does cause declines in economic well being (Smock, Manning, and Gupta 1999). Future research could also investigate whether these estimated effects vary across different racial, ethnic, and other sociodemographic groups.

\section{Acknowledgement}

This research was supported by a grant, 5 R24 HD042849, Population Research Center, awarded to the Population Research Center at The University of Texas at Austin by the Eunice Kennedy Shriver National Institute of Health and Child Development. Opinions reflect those of the authors and do not necessarily reflect those of the granting agency. 


\section{References}

Bean, F.D., Berg, R.R., and Van Hook, J.V.W. (1996). Socioeconomic and cultural incorporation and marital disruption among Mexican Americans. Social Forces 75(2): 593-617. doi:10.2307/2580415.

Binstock, G. and Thornton, A. (2003). Separations, reconciliations, and living apart in cohabiting and marital unions. Journal of Marriage and Family 65(2): 432-443. doi:10.1111/j.1741-3737.2003.00432.x.

Bumpass, L., Raley, R.K., and Sweet, J.A. (1995). The changing character of stepfamilies: Implications of cohabitation and nonmarital childbearing. Demography 32(3): 425-436. doi:10.2307/2061689.

Bumpass, L. and Sweet, J. (1989). National estimates of cohabitation. Demography 26(4): 615-625. doi:10.2307/2061261.

Bumpass, L., Sweet, J., and Castro Martin, T. (1990). Changing patterns of remarriage. Journal of Marriage and the Family 52(3): 747-756. doi:10.2307/352939.

Cherlin, A.J. (1992). Marriage, divorce, remarriage. Cambridge: Harvard University Press.

Cherlin, A.J. (2009). The Marriage-Go-Round. New York: Knopf.

Gierveld, J.D. (2004). Remarriage, Unmarried Cohabitation, Living Apart Together: Partner Relationships Following Bereavement or Divorce. Journal of Marriage and Family 66(1): 236-243. doi:10.1111/j.0022-2445.2004.00015.x.

Goldstein, J.R. and Kenney, C.T. (2001). Marriage delayed or marriage forgone? New cohort forecast of first marriage for US women. American Sociological Review 66(4): 506-519. doi:10.2307/3088920.

Holden, K.C. and Smock, P.J. (1991). The economic costs of marital dissolution: Why do women bear a disproportionate cost? Annual Review of Sociology 17: 51-78. doi:10.1146/annurev.so.17.080191.000411.

Koo, H.P., Suchindran, C.M., and Griffith, J.D. (1984). The effects of children on divorce and re-marriage: A multivariate analysis of life table probabilities. Population Studies 38(3): 451-471. doi:10.2307/2174134.

Manning, W.D. and Landale, N.S. (1996). Racial and ethnic differences in the role of cohabitation in premarital childbearing. Journal of Marriage and the Family 58(1): 63-77. doi:10.2307/353377. 
Martin, S.P. (2006). Trends in marital dissolution by women's education in the United States. Demographic Research 15(20): 537-560. doi:10.4054/DemRes.2006. 15.20 .

McCarthy, J. (1978). A comparison of the probability of the dissolution of first and second marriages. Demography 15(3): 345-359. doi:10.2307/2060655.

Morgan, L.A. (1988). Outcomes of marital separation: A longitudinal test of predictors. Journal of Marriage and the Family 50(2): 493-498. doi:10.2307/352014.

Morrison, D.R. and Ritualo, A. (2000). Routes to children's economic recovery after divorce: Are cohabitation and remarriage equivalent? American Sociological Review 65(4): 560-580. doi:10.2307/2657383.

Oppenheimer, V.K. (2003). Cohabitating and marriage during young men's careerdevelopment process. Demography 40(1): 127-149. doi:10.1353/dem.2003. 0006.

Oropesa, R.S. and Landale, N.S. (2004). The future of marriage and Hispanics. Journal of Marriage and Family 66(4): 901-920. doi:10.1111/j.0022-2445.2004.00061.x.

Phillips, J.A. and Sweeney, M.M. (2005). Premarital cohabitation and marital disruption among White, Black, and Mexican American women. Journal of Marriage and Family 67(2): 296-314. doi:10.1111/j.0022-2445.2005.00117.x.

Phillips, J.A. and Sweeney, M.M. (2006). Can differential exposure to risk factors explain recent racial and ethnic variation in marital disruption? Social Science Research 35(2): 409-434. doi:10.1016/j.ssresearch.2005.04.002.

Raley, R.K. (1996). A shortage of marriageable men? A note on the role of cohabitation in Black-White differences in marriage rate. American Sociological Review 61(6): 973-983. doi:10.2307/2096303.

Raley, R.K. and Bumpass, L. (2003). The topography of the divorce plateau: Level and trends in union stability in the United States after 1980. Demographic Research 8(8): 245-260. doi:10.4054/DemRes.2003.8.8.

Raley, R.K., Durden, E.T., and Wildsmith, E. (2004). Understanding Mexican American marriage patterns using a life course approach. Social Science Quarterly 85(4): 872-890. doi:10.1111/j.0038-4941.2004.00249.x.

Raley, R.K. and Wildsmith, E. (2004). Cohabitation and children's family instability. Journal of Marriage and Family 66(1): 210-219. doi:10.1111/j.00222445.2004.00014.x-i1. 
Ruggles, S. (1997). The rise of divorce and separation in the United States, 1880-1990. Demography 34(4): 455-466. doi:10.2307/3038300.

Smock, P.J. (1990). Remarriage patterns of Black and White women: Reassessing the role of educational attainment. Demography 27(3): 467-473. doi: $10.2307 / 2061380$.

Smock, P.J. (2000). Cohabitation in the United States: An appraisal of research themes, findings, and implications. Annual Review of Sociology 26(1): 1-20. doi:10.1146/annurev.soc.26.1.1.

Smock, P.J., Manning, W.D., and Gupta, S. (1999). The effect of marriage and divorce on women's economic well-being. American Sociological Review 64(6): 794812. doi: $10.2307 / 2657403$.

South, S. and Spitze, G. (1986). Determinants of divorce over the marital life course. American Sociological Review 51(4): 583-590. doi:10.2307/2095590.

Spanier, G.B. and Glick, P.C. (1980). Mate selection differentials between whites and blacks in the United States. Social Forces 58(3): 707-725. doi:10.2307/2577180.

Sweeney, M.M. (2002). Two decades of family change: The shifting economic foundations of marriage. American Sociological Review 67(1): 132-147. doi: $10.2307 / 3088937$.

Sweeney, M.M. (2010). Remarriage and stepfamilies: Strategic sites for family scholarship in the 21st century. Journal of Marriage and Family 72(3): 667-684. doi:10.1111/j.1741-3737.2010.00724.x.

Sweeney, M.M. and Phillips, J.A. (2004). Understanding racial differences in marital disruption: Recent trends and explanations. Journal of Marriage and Family 66(3): 639-650. doi:10.1111/j.0022-2445.2004.00043.x.

Teachman, J.D. (1986). First and second marital dissolution: A decomposition exercise for Whites and Blacks. The Sociological Quarterly 27(4): 571-590. doi:10.1111/j.1533-8525.1986.tb00279.x.

Teachman, J.D. and Heakert, A. (1985). The impact of age and children on remarriage. Journal of Family Issues 6(2): 185-203. doi:10.1177/019251385006002003.

Teachman, J.S. (2002). Stability across cohorts in divorce risk factors. Demography 39(2): 331-351. doi:10.1353/dem.2002.0019.

Thornton, A. (1977). Decomposing the re-marriage process. Population Studies 31(2): 383-392. doi: $10.2307 / 2173923$. 
Udry, R.J. (1966). Marital instability by race, sex, education, and occupation using 1960 census data. The American Journal of Sociology 72(2): 203-209. doi:10.1086/224279.

Wildsmith, E. and Raley, R.K. (2006). Race-ethnic differences in nonmarital fertility: A focus on Mexican American women. Journal of Marriage and Family 68(2): 491-508. doi:10.1111/j.1741-3737.2006.00267.x. 